Economic and Environmental Geology

Research Paper

\title{
Studies on Heavy Metal Characteristics by Part of Fish in Upper Region of Nakdong River
}

\author{
Hee Won Kwon ${ }^{1}$, Young Hun $\mathrm{Kim}^{1}$, Jeong Jin Kim ${ }^{2, *}$ \\ ${ }^{1}$ Department of Environmental Engineering, Andong National University, Andong 36729, Korea \\ ${ }^{2}$ Department of Earth and Environmental Sciences, Andong National University, Andong 36729, Korea \\ *Corresponding author : jjkim@andong.ac.kr
}

\section{ARTICLE INFORMATION}

Manuscript received 11 January 2022

Received in revised form 18 February 2022

Manuscript accepted 20 February 2022

Available online 28 February 2022

DOI : http://dx.doi.org/10.9719/EEG.2022.55.1.19

\section{Research Highlights}

- Fish live in upper region of Nakdong River were analyzed heavy metals by separated into muscle, gill, stomach and liver part.

- Average concentration of muscle part is lower than other parts in all heavy metal items except mercury.

- The concentration of heavy metals varies by part of muscle, gill, stomach and liver.

\begin{abstract}
Fish that inhabited in the watersheds of Andong, Imha and Yeongju Dam in the upper Nakdong River were analyzed heavy metals by separated into muscle, gill, stomach and liver part. Thirteen fish species such as dark chub, skygager, coreoperca herzi, Korean piscivorous chub, cornet fish, Japan crucian carp, catfish, bass, crucian carp, mandarin fish, carp, long-nosed barbel, Korean sharpbelly were analyzed using ICP/MS. The results of the analysis based on the overall average concentration showed that the muscle part is lower than other parts in all heavy metal items except mercury. The gill part showed high concentrations of chromium, manganese, nickel, and lead, the stomach part has high zinc, and the liver part showed high concentrations of iron, copper, arsenic, and cadmium.
\end{abstract}

Keywords : Nakdong river, fish, heavy metal, muscle, gill

Citation: Kwon, H.W., Kim, Y.H., Kim, J.J. (2022) Studies on Heavy Metal Characteristics by Part of Fish in Upper Region of Nakdong River. Korea Economic and Environmental Geology, v.55, p.19-27, doi:10.9719/EEG2022.55.1.19.

This is an Open Access article distributed under the terms of the Creative Commons Attribution Non-Commercial License (http://creativecommons.org/ licenses/by-nc/3.0) which permits unrestricted non-commercial use, distribution, and reproduction in any medium, provided original work is properly cited. pISSN 1225-7281; eISSN 2288-7962/C2022 The KSEEG. Printed by Hanrimwon Publishing Company. All rights reserved. 


\title{
연구논문
}

\section{낙동강 상류 서식 어류의 부위별 중금속 분포 특성}

\author{
권희원 ${ }^{1} \cdot$ 김영훈 ${ }^{1} \cdot$ 김정진 ${ }^{2, *}$ \\ ${ }^{1}{ }^{1}$ 난동대학교 환경공학과 \\ ${ }^{2}$ 안동대학교 지구환경과학과 \\ *책임저자 : jjkim@andong.ac.kr
}

\section{요 약}

낙동강 상류지역의 안동댐, 임하댐, 영주댐 유역에 서식하는 물고기에 대하여 근육부, 아가미, 위, 간 부위로 분리하여 중금속 분석을 수행하였다. 분석한 물고기는 갈겨니(dark chub), 강준치(skygager), 꺽지(coreoperca herzi), 끄리(Korean piscivorous chub), 누치(cornet fish), 떡붕어(Japan crucian carp), 메기(catfish), 배스(bass), 붕어(crucian carp), 쏘가리(mandarin fish), 잉어(carp), 참 마자(long-nosed barbel), 치리(Korean sharpbelly) 등 13개 어종으로 ICP/MS를 이용하여 분석하였다. 분석 결과 전체 평균 농도 를 기준으로 근육부는 수은을 제외한 모든 중금속 항목에서 다른 부위에 비해 낮았다. 아가미 부위는 크롬, 망간, 니켈, 납, 위 부위는 아연, 간 부위는 철, 구리, 비소, 카드뮴이 다른 금속에 비해 높은 농도값을 나타내었다.

주요어 : 낙동강, 물고기, 중금속, 근육부, 아가미

\section{1. 서 론}

인간 활동으로 발생한 오염물질은 수계로 유입되어 순 환과정을 거치면서 결과적으로 저장고 역할을 하는 퇴적 물에 저장되며 지화학적 환경 변화에 따라 다시 수계로 용출된다. 낙동강 상류 서식 물고기의 체내 중금속의 축 적 경로는 오염원으로부터 퇴적물 및 수질로의 이동 가 능성이 있다. 생물체 내의 중금속은 주변 환경의 중금속 농도를 반영하고 생물체 내의 총 중금속 함량은 각 조직 에 분포하고 있는 중금속의 합이라고 볼 수 있다. 또한, 중금속은 모든 조직에 대해 일정한 분포를 보이지 않고 근육부, 간, 신장, 아가미 등에 선택적으로 축적되므로 많 은 양의 중금속을 축적하는 능력이 있는 조직을 중금속 오염 감시에 선별적으로 이용하면 더욱 효과적인 오염조 사를 할 수 있다(Mason and Simkiss, 1993). 물고기의 체 내 중금속은 간, 위, 아가미 부위에 중금속이 농집되지만 이 부위는 식용으로 사용되지 않기 때문에 주변 환경에 존재하는 금속의 좋은 생체 모니터링 대상이 될수 있다 (Rajeshkumar and Li, 2018). 어류 중의 중금속 함량의 차 이는 시료의 채취 시기 및 오염원에서 방출되는 중금속 량의 변화 또는 수중 생태계 내에서의 생물학적 활성도 변화 등의 차이에 기인하기 때문에 정확한 판단을 위해 서는 같은 시기, 같은 장소의 중금속 특성에 관한 연구 가 이루어져야 한다(Shin et al., 2010).

안동댐 상류 지역의 퇴적물은 중금속으로 오염되어 있
어 이곳에 서식하는 물고기 체내에 중금속 축적 가능성 이 큰 것으로 알려져 있다(Seo et al., 2019a). 안동댐과 임하댐 떡붕어에 대한 부위별 중금속 분석 결과에 의하 면 부위별로 농집되는 중금속의 종류와 정도가 다르게 나타났다(Seo et al., 2019b). 또한, 안동·임하호에 서식하 는 수종 어류의 조직 내 중금속 함량연구 결과에 의하면 임하호보다 안동호에 서식하는 어류의 체내 중금속 함량 이 높으며, 근육부가 뼈와 아가미 조직보다 낮은 값을 나 타내었다(Kim et al., 2009, Shin et al., 2010). 서울에 유 통 중인 해산 어류의 부위별 중금속 분석 결과에 의하면 $\mathrm{Pb}, \mathrm{Cd}$ 및 $\mathrm{Cu}$ 의 경우 내장에서 가장 높고 아가미, 골격, 근육의 순으로 감소하며 $\mathrm{Zn}$ 은 아가미에서 최고 함량을 보인다(Hwang et al., 1989).

본 연구의 목적은 낙동강 상류에 서식하는 물고기에 대 하여 부위별 중금속 분포 특성을 파악하는 것이며, 이 결 과는 다른 수계의 어류 체내 중금속 축적 및 오염도를 비교하는 데 기초 자료로 활용할 수 있을 것으로 판단된 다. 이를 위해 낙동강 상류 안동댐, 임하댐, 영주댐 유역 에서 채집된 물고기 중 체장이 $20 \mathrm{~cm}$ 이상인 물고기를 대 상으로 근육부, 아가미, 위, 간으로 분리하여 중금속 분 석을 수행하였다.

\section{2. 연구 방법}

낙동강 상류에 서식하는 어류의 부위별 중금속 특성을 


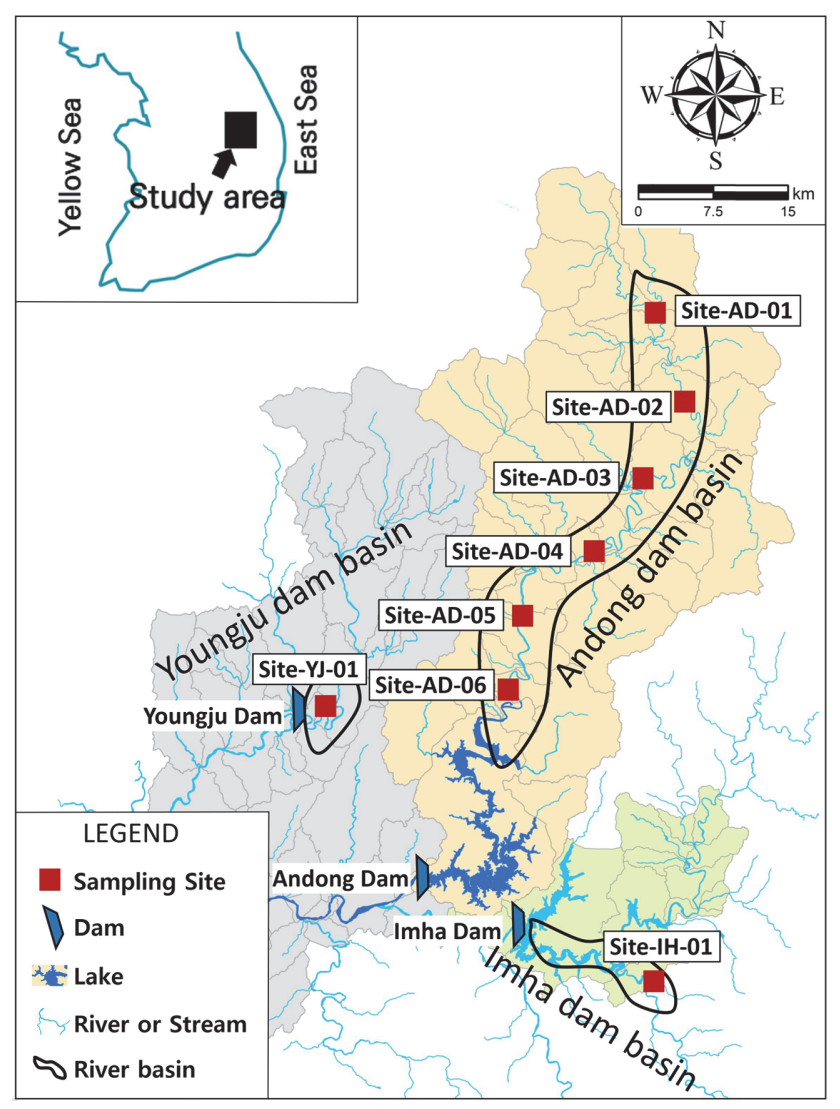

Fig. 1. Sampling site in Andong, Imha and Youngju dam basin area.

규명하기 위하여 안동댐 유역(Site-AD-01 06), 임하댐 유 역(Site-IH-01), 영주댐 유역(Site-YJ-01) 등 8개 지점에서 주로 그물을 이용하여 채취하였다(Fig. 1). 채취한 어류 중 체장 $20 \mathrm{~cm}$ 이상의 어종을 대상으로 근육부(muscle), 아가미(gill), 위(stomach), 간(liver)을 분리하여 생체시료 를 준비하였다. Table 1 은 부위별로 분석한 어종과 개체 수 및 먹이 형태를 나타낸 것으로 잡식성 물고기(omnivores fish)는 갈겨니(dark chub), 떡붕어(Japan crucian carp), 붕 어(crucian carp), 잉어(carp), 참마자(long-nosed barbel) 등 이며, 육식성 물고기(carnivores fish)는 강준치(skygager), 꺽지(coreoperca herz), 끄리(Korean piscivorous chub), 누 치(cornet fish), 메기(catfish), 배스(bass), 쏘가리(mandarin fish), 치리(Korean sharpbelly) 등으로 총 13개 어종 36개 체이다. 분석 시료 중 가장 많은 개체는 붕어로 5 개 지 점 9 개체이며, 그 외 갈겨니 4개 지점 4 개체, 배스 3 개 지점 4개체 등이다. 유역별로는 안동댐 유역(Site-AD01 06) 12개 어종 26개체, 임하댐 유역(Site-IH-01) 6개 어종, 7개체, 영주댐 유역(Site-YJ-01) 3개 어종 3개체 등 으로 안동댐 유역의 물고기가 대부분을 차지한다.

분석에 이용한 물고기는 각 어종별로 최소 1 개체부터 최대 9개체에 대해 각 부위별로 농집되는 주요 중금속 특성 알아보기 위하여 크롬 $(\mathrm{Cr})$, 망간 $(\mathrm{Mn})$, 철 $(\mathrm{Fe})$, 니켈 $(\mathrm{Ni})$, 구리 $(\mathrm{Cu})$, 아연 $(\mathrm{Zn})$, 비소 $(\mathrm{As})$, 카드뮴 $(\mathrm{Cd})$, 수은 $(\mathrm{Hg})$, 납 $(\mathrm{Pb})$ 등 10 개 항목에 대하여 분석을 수행하였다. 중금 속 분석은 기본적으로 식품의약품안전처 식품가공공전, 일반시험법, 식품중 유해물질, 중금속 분석법에 준하여 시료 준비를 하였다. 분석 시료 준비는 각 부위별 생체 시료 $0.5 \sim 1.0 \mathrm{~g}$ 을 $15 \mathrm{ml}$ 튜브에 넣고 질산 $10 \mathrm{ml}$ 를 가하 여 4시간 동안 마이크로웨이브를 이용하여 분해한 후 희석 하여 분석하였다. 수은은 수은 분석기(DMA-80, Milestone, Italy)를 이용하였으며, 그 외 중금속은 유도결합플라즈마 /질량분석기(Agilent $7800 \mathrm{ICP} / \mathrm{MS}$, Agilent, USA)로 분석 하였다.

Table 1. Fish species of analysis for each part (13 fish species 36 specimens)

\begin{tabular}{|c|c|c|c|c|c|c|c|c|c|}
\hline Fish species & $\begin{array}{l}\text { Site-AD- } \\
01\end{array}$ & $\begin{array}{l}\text { Site-AD- } \\
02\end{array}$ & $\begin{array}{l}\text { Site-AD- } \\
03\end{array}$ & $\begin{array}{l}\text { Site-AD- } \\
04\end{array}$ & $\begin{array}{l}\text { Site-AD- } \\
05\end{array}$ & $\begin{array}{l}\text { Site-AD- } \\
06\end{array}$ & $\begin{array}{c}\text { Site-IH- } \\
01\end{array}$ & $\begin{array}{c}\text { Site-YJ- } \\
01\end{array}$ & $\begin{array}{c}\text { Total number } \\
\text { of samples }\end{array}$ \\
\hline Dark chub & 1 & 1 & 1 & 1 & & & & & 4 \\
\hline Skygager & & & & & & 1 & 1 & 1 & 3 \\
\hline Coreoperca herzi & & & 1 & 1 & & & & & 2 \\
\hline Korean piscivorous chub & & & & & 1 & & & & 1 \\
\hline Cornet fish & & & & & 1 & & 1 & & 2 \\
\hline Japan crucian carp & & & & & & 2 & & & 2 \\
\hline Catfish & 1 & 1 & & 1 & & & & & 3 \\
\hline Bass & & & & & & 2 & 1 & 1 & 4 \\
\hline Crucian carp & & & 2 & 2 & & 2 & 2 & 1 & 9 \\
\hline Mandarin fish & & & & & & & 1 & & 1 \\
\hline Carp & & & & & & 2 & & & 2 \\
\hline Long-nosed barbel & & 1 & & & & & & & 1 \\
\hline Korean sharpbelly & & & & & & 1 & 1 & & 2 \\
\hline Total number of samples & 2 & 3 & 4 & 5 & 2 & 10 & 7 & 3 & 36 \\
\hline
\end{tabular}




\section{3. 결과 및 고찰}

\section{1. 물고기의 종류에 따른 부위별 중금속 농도}

Table 2와 Fig. 2는 물고기의 종류에 따른 부위별 중금 속 농도를 나타낸 것이다. 갈겨니는 망간, 철, 아연, 비소, 카드뮴, 납이 간에, 니켈과 구리는 위에 높은 값을 나타 내었다. 근육부에 철과 망간, 아가미에는 크롬, 망간, 아
연, 카드뮴, 납이, 위에는 망간, 철, 니켈, 구리, 아연, 비 소, 납, 간에는 크롬, 망간 아연, 비소가 높으며 특히 망 간, 아연, 납은 모든 부위에서 평균 농도보다 높았다. 강 준치 해부 시료는 근육부에 비소와 수은, 아가미에는 크 롬, 망간, 니켈, 납, 위에는 아연, 간에는 철, 구리, 카드 뮴이 다른 부위에 비해 농도가 높았다. 꺽지는 주로 간 에 중금속이 농집되며 끄리는 아가미에 크롬, 망간, 니켈,
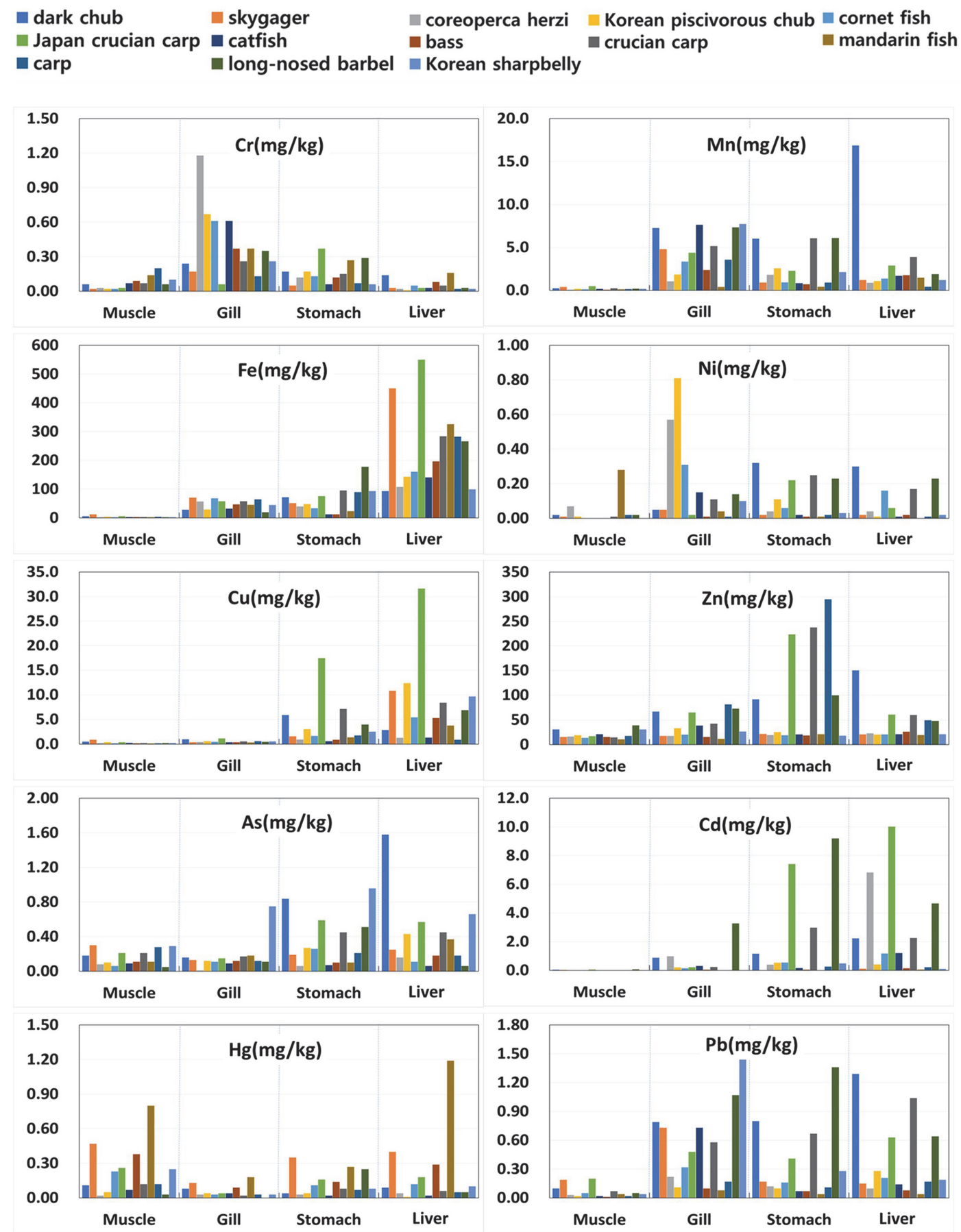

Fig. 2. Heavy metal concentration by each part of all fish. 
Table 2. Average value of chemical analysis for each part of muscle, gill, stomach, Liver

\begin{tabular}{|c|c|c|c|c|c|c|c|c|c|c|c|c|}
\hline $\begin{array}{c}\text { Fish } \\
\text { species }\end{array}$ & $\begin{array}{l}\text { Part of } \\
\text { fish }\end{array}$ & $\begin{array}{c}\mathrm{Cr} \\
(\mathrm{mg} / \mathrm{kg})\end{array}$ & $\begin{array}{c}\mathrm{Mn} \\
(\mathrm{mg} / \mathrm{kg})\end{array}$ & $\begin{array}{c}\mathrm{Fe} \\
(\mathrm{mg} / \mathrm{kg})\end{array}$ & $\begin{array}{c}\mathrm{Ni} \\
(\mathrm{mg} / \mathrm{kg})\end{array}$ & $\begin{array}{c}\mathrm{Cu} \\
(\mathrm{mg} / \mathrm{kg})\end{array}$ & $\begin{array}{c}\mathrm{Zn} \\
(\mathrm{mg} / \mathrm{kg})\end{array}$ & $\begin{array}{c}\text { As } \\
(\mathrm{mg} / \mathrm{kg})\end{array}$ & $\begin{array}{c}\mathrm{Cd} \\
(\mathrm{mg} / \mathrm{kg})\end{array}$ & $\begin{array}{c}\mathrm{Hg} \\
(\mathrm{mg} / \mathrm{kg})\end{array}$ & $\begin{array}{c}\mathrm{Pb} \\
(\mathrm{mg} / \mathrm{kg})\end{array}$ & Diet type \\
\hline \multirow{4}{*}{ Dark chub } & Muscle & 0.06 & 0.24 & 6.11 & 0.02 & 0.51 & 31.01 & 0.18 & 0.05 & 0.11 & 0.10 & \multirow{4}{*}{ Omnivores } \\
\hline & Gill & 0.24 & 7.27 & 28.41 & 0.05 & 0.99 & 66.73 & 0.16 & 0.88 & 0.08 & 0.79 & \\
\hline & Stomach & 0.17 & 6.01 & 71.94 & 0.32 & 5.89 & 91.43 & 0.84 & 1.16 & 0.04 & 0.80 & \\
\hline & Liver & 0.14 & 16.88 & 93.24 & 0.30 & 2.88 & 150.44 & 1.58 & 2.23 & 0.09 & 1.29 & \\
\hline \multirow{4}{*}{ Skygager } & Muscle & 0.02 & 0.39 & 12.11 & 0.01 & 0.91 & 15.42 & 0.30 & 0.03 & 0.47 & 0.19 & \multirow{4}{*}{ Carnivores } \\
\hline & Gill & 0.17 & 4.79 & 70.16 & 0.05 & 0.40 & 17.42 & 0.13 & 0.01 & 0.13 & 0.73 & \\
\hline & Stomach & 0.05 & 0.90 & 51.00 & 0.02 & 1.60 & 21.47 & 0.19 & 0.02 & 0.35 & 0.17 & \\
\hline & Liver & 0.03 & 1.19 & 450.85 & 0.02 & 10.85 & 20.72 & 0.25 & 0.12 & 0.40 & 0.15 & \\
\hline \multirow{4}{*}{$\begin{array}{l}\text { Coreoperca } \\
\text { herzi }\end{array}$} & Muscle & 0.03 & 0.08 & 2.22 & 0.07 & 0.20 & 16.14 & 0.08 & 0.01 & 0.02 & 0.03 & \multirow{4}{*}{ Carnivores } \\
\hline & Gill & 1.18 & 1.05 & 57.40 & 0.57 & 0.43 & 17.39 & 0.01 & 0.98 & 0.03 & 0.22 & \\
\hline & Stomach & 0.12 & 1.81 & 39.40 & 0.04 & 0.95 & 19.31 & 0.06 & 0.40 & 0.03 & 0.12 & \\
\hline & Liver & 0.02 & 0.88 & 107.96 & 0.04 & 1.29 & 22.76 & 0.16 & 6.83 & 0.04 & 0.10 & \\
\hline \multirow{4}{*}{$\begin{array}{c}\text { Korean } \\
\text { piscivorous } \\
\text { chub }\end{array}$} & Muscle & 0.02 & 0.17 & 3.57 & 0.01 & 0.39 & 19.02 & 0.10 & 0.01 & 0.05 & 0.02 & \multirow{4}{*}{ Carnivores } \\
\hline & Gill & 0.67 & 1.83 & 29.08 & 0.81 & 0.58 & 33.10 & 0.12 & 0.21 & 0.04 & 0.11 & \\
\hline & Stomach & 0.17 & 2.56 & 47.90 & 0.11 & 3.03 & 25.20 & 0.27 & 0.53 & 0.04 & 0.10 & \\
\hline & Liver & 0.01 & 1.07 & 143.04 & 0.01 & 12.35 & 20.04 & 0.43 & 0.41 & 0.01 & 0.28 & \\
\hline \multirow{4}{*}{ Cornet fish } & Muscle & 0.02 & 0.11 & 1.88 & 0.01 & 0.16 & 13.81 & 0.06 & 0.01 & 0.23 & 0.05 & \multirow{4}{*}{ Carnivores } \\
\hline & Gill & 0.61 & 3.35 & 68.37 & 0.31 & 0.49 & 20.19 & 0.11 & 0.14 & 0.03 & 0.32 & \\
\hline & Stomach & 0.13 & 0.93 & 33.53 & 0.06 & 1.68 & 18.62 & 0.26 & 0.54 & 0.11 & 0.16 & \\
\hline & Liver & 0.05 & 1.37 & 160.75 & 0.16 & 5.45 & 20.55 & 0.11 & 1.18 & 0.12 & 0.21 & \\
\hline \multirow{4}{*}{$\begin{array}{l}\text { Japan crucian } \\
\text { carp }\end{array}$} & Muscle & 0.03 & 0.48 & 6.20 & 0.01 & 0.38 & 17.02 & 0.21 & 0.06 & 0.26 & 0.20 & \multirow{4}{*}{ Omnivores } \\
\hline & Gill & 0.06 & 4.39 & 57.72 & 0.02 & 1.14 & 64.98 & 0.15 & 0.22 & 0.04 & 0.48 & \\
\hline & Stomach & 0.37 & 2.28 & 75.83 & 0.22 & 17.45 & 223.69 & 0.59 & 7.41 & 0.16 & 0.41 & \\
\hline & Liver & 0.03 & 2.88 & 550.23 & 0.06 & 31.64 & 60.71 & 0.57 & 10.03 & 0.18 & 0.63 & \\
\hline \multirow{4}{*}{ Catfish } & Muscle & 0.07 & 0.16 & 2.76 & 0.01 & 0.27 & 21.01 & 0.09 & 0.01 & 0.07 & 0.02 & \multirow{4}{*}{ Carnivores } \\
\hline & Gill & 0.61 & 7.62 & 32.06 & 0.15 & 0.37 & 38.58 & 0.09 & 0.31 & 0.04 & 0.73 & \\
\hline & Stomach & 0.06 & 0.84 & 12.51 & 0.02 & 0.59 & 20.33 & 0.07 & 0.16 & 0.02 & 0.07 & \\
\hline & Liver & 0.03 & 1.69 & 141.18 & 0.01 & 1.33 & 20.76 & 0.06 & 1.21 & 0.02 & 0.14 & \\
\hline \multirow{4}{*}{ Bass } & Muscle & 0.09 & 0.08 & 2.57 & 0.01 & 0.18 & 15.26 & 0.11 & 0.01 & 0.38 & 0.01 & \multirow{4}{*}{ Carnivores } \\
\hline & Gill & 0.37 & 2.38 & 46.83 & 0.01 & 0.39 & 15.31 & 0.12 & 0.04 & 0.09 & 0.10 & \\
\hline & Stomach & 0.12 & 0.71 & 12.10 & 0.01 & 0.89 & 18.26 & 0.10 & 0.05 & 0.14 & 0.07 & \\
\hline & Liver & 0.08 & 1.76 & 196.96 & 0.02 & 5.31 & 26.23 & 0.18 & 0.14 & 0.29 & 0.08 & \\
\hline \multirow{4}{*}{ Crucian carp } & Muscle & 0.07 & 0.25 & 3.27 & 0.01 & 0.22 & 14.60 & 0.21 & 0.01 & 0.12 & 0.07 & \multirow{4}{*}{ Omnivores } \\
\hline & Gill & 0.26 & 5.17 & 57.82 & 0.11 & 0.56 & 42.31 & 0.17 & 0.23 & 0.02 & 0.58 & \\
\hline & Stomach & 0.15 & 6.06 & 95.14 & 0.25 & 7.15 & 238.20 & 0.45 & 2.98 & 0.08 & 0.67 & \\
\hline & Liver & 0.05 & 3.88 & 284.02 & 0.17 & 8.40 & 59.72 & 0.45 & 2.26 & 0.06 & 1.04 & \\
\hline \multirow{4}{*}{ Mandarin fish } & Muscle & 0.14 & 0.11 & 2.33 & 0.28 & 0.14 & 10.86 & 0.11 & 0.01 & 0.80 & 0.04 & \multirow{4}{*}{ Carnivores } \\
\hline & Gill & 0.37 & 0.38 & 45.34 & 0.04 & 0.34 & 11.61 & 0.18 & 0.01 & 0.18 & 0.08 & \\
\hline & Stomach & 0.27 & 0.42 & 23.54 & 0.01 & 1.38 & 20.86 & 0.10 & 0.01 & 0.27 & 0.04 & \\
\hline & Liver & 0.16 & 1.46 & 326.08 & 0.01 & 3.75 & 19.36 & 0.37 & 0.06 & 1.19 & 0.04 & \\
\hline & Muscle & 0.20 & 0.15 & 3.45 & 0.02 & 0.19 & 17.39 & 0.28 & 0.01 & 0.12 & 0.02 & \\
\hline Corn & Gill & 0.13 & 3.58 & 64.70 & 0.01 & 0.62 & 81.25 & 0.12 & 0.01 & 0.03 & 0.17 & \\
\hline Carp & Stomach & 0.07 & 0.90 & 89.29 & 0.02 & 1.75 & 295.11 & 0.21 & 0.26 & 0.07 & 0.11 & Umnivores \\
\hline & Liver & 0.02 & 0.41 & 282.65 & 0.01 & 0.91 & 49.08 & 0.18 & 0.22 & 0.05 & 0.17 & \\
\hline
\end{tabular}


Table 2. Continued

\begin{tabular}{|c|c|c|c|c|c|c|c|c|c|c|c|c|}
\hline $\begin{array}{c}\text { Fish } \\
\text { species }\end{array}$ & $\begin{array}{l}\text { Part of } \\
\text { fish }\end{array}$ & $\begin{array}{c}\mathrm{Cr} \\
(\mathrm{mg} / \mathrm{kg})\end{array}$ & $\begin{array}{c}\mathrm{Mn} \\
(\mathrm{mg} / \mathrm{kg})\end{array}$ & $\begin{array}{c}\mathrm{Fe} \\
(\mathrm{mg} / \mathrm{kg})\end{array}$ & $\begin{array}{c}\mathrm{Ni} \\
(\mathrm{mg} / \mathrm{kg})\end{array}$ & $\begin{array}{c}\mathrm{Cu} \\
(\mathrm{mg} / \mathrm{kg})\end{array}$ & $\begin{array}{c}\mathrm{Zn} \\
(\mathrm{mg} / \mathrm{kg})\end{array}$ & $\begin{array}{c}\text { As } \\
(\mathrm{mg} / \mathrm{kg})\end{array}$ & $\begin{array}{c}\mathrm{Cd} \\
(\mathrm{mg} / \mathrm{kg})\end{array}$ & $\begin{array}{c}\mathrm{Hg} \\
(\mathrm{mg} / \mathrm{kg})\end{array}$ & $\begin{array}{c}\mathrm{Pb} \\
(\mathrm{mg} / \mathrm{kg})\end{array}$ & Diet type \\
\hline \multirow{4}{*}{$\begin{array}{l}\text { Long-nosed } \\
\text { barbel }\end{array}$} & Muscle & 0.06 & 0.19 & 2.35 & 0.02 & 0.20 & 38.90 & 0.05 & 0.08 & 0.03 & 0.05 & \multirow{4}{*}{ Omnivores } \\
\hline & Gill & 0.35 & 7.33 & 19.80 & 0.14 & 0.48 & 72.96 & 0.11 & 3.27 & 0.01 & 1.07 & \\
\hline & Stomach & 0.29 & 6.10 & 177.57 & 0.23 & 4.00 & 99.74 & 0.51 & 9.20 & 0.25 & 1.36 & \\
\hline & Liver & 0.03 & 1.88 & 266.47 & 0.23 & 6.91 & 47.82 & 0.06 & 4.66 & 0.05 & 0.64 & \\
\hline \multirow{4}{*}{$\begin{array}{c}\text { Korean } \\
\text { sharpbelly }\end{array}$} & Muscle & 0.10 & 0.18 & 2.17 & 0.01 & 0.23 & 30.66 & 0.29 & 0.01 & 0.25 & 0.04 & \multirow{4}{*}{ Carnivores } \\
\hline & Gill & 0.26 & 7.74 & 44.86 & 0.10 & 0.57 & 26.40 & 0.75 & 0.02 & 0.03 & 1.51 & \\
\hline & Stomach & 0.06 & 2.13 & 93.09 & 0.03 & 2.53 & 17.76 & 0.96 & 0.49 & 0.08 & 0.28 & \\
\hline & Liver & 0.02 & 1.20 & 99.13 & 0.02 & 9.69 & 20.88 & 0.66 & 0.10 & 0.11 & 0.19 & \\
\hline \multirow{4}{*}{ Average } & Muscle & 0.07 & 0.20 & 3.92 & 0.03 & 0.31 & 20.08 & 0.16 & 0.02 & 0.22 & 0.06 & \\
\hline & Gill & 0.41 & 4.38 & 47.89 & 0.18 & 0.57 & 39.09 & 0.17 & 0.49 & 0.06 & 0.53 & \\
\hline & Stomach & 0.16 & 2.43 & 63.30 & 0.10 & 3.76 & 85.38 & 0.35 & 1.79 & 0.13 & 0.34 & \\
\hline & Liver & 0.05 & 2.81 & 238.66 & 0.08 & 7.75 & 41.47 & 0.39 & 2.27 & 0.20 & 0.38 & \\
\hline
\end{tabular}

아연이, 간에는 철, 비소, 납의 농도가 높고 근육부에는 비소의 농도가 높게 나타났다. 누치는 아가미에 크롬, 망 간, 니켈, 납이, 간에 철, 구리, 카드뮴이 농집되는 경향 이 있다. 떡붕어는 아가미에 망간, 위에 크롬, 니켈, 아연, 비소, 간에는 철, 구리, 카드뮴, 납의 농도가 높았다. 니 켈과 아연은 근육부, 비소와 수은은 아가미 부위를 제외 하고 전체 평균값보다 높으며, 철과 구리는 모든 부위에 서 평균값보다 높게 나타났다.

메기는 아가미에 크롬, 망간, 니켈, 아연, 납이, 간에는 철, 그리, 카드뮴의 농도가 높으며 비소와 수은은 모든 부위에서 대체로 낮았으며, 배스는 주로 간에 농집되었 다. 붕어는 근육부에 수은, 아가미에 크롬, 위에 망간, 니 켈, 아연, 비소, 카드뮴, 간에는 철, 구리, 납의 농도가 높 다. 위에 망간, 철, 니켈, 구리, 아연, 비소, 카드뮴, 납이, 간에는 망간과 아연, 납이 평균값보다 높았다. 쏘가리는 주로 간에 잉어는 위에 구리, 아연, 카드뮴이, 간에는 철 과 납이 농집되었다. 참마자는 아가미 부위에 크롬, 망간, 위에 니켈, 아연, 비소, 카드뮴, 수은, 납, 간에는 철과 납 이 높은 값을 나타내었다. 아가미에 망간, 카드뮴, 납이, 위에 크롬, 망간, 철, 니켈, 비소, 카드뮴, 수은, 납이, 간 에는 니켈, 납이 평균값보다 높으며 아연과 카드뮴은 4 부위 모두 평균값보다 높게 나타났다. 치리는 아연과 수 은이 근육부에 크롬과 망간, 니켈, 납이 아가미에, 비소
와 카드뮴이 위에, 간에는 철과 아연의 농도가 높다.

잡식성 어류(omnivores fish)인 갈겨니, 떡붕어, 붕어, 잉어, 참마자는 철, 구리, 아연의 농도가 평균값보다 높 은 경향을 나타내며, 특히 떡붕어, 붕어, 잉어의 위에 아 연의 농도는 각각 $223.69 \mathrm{mg} / \mathrm{kg}, 238.20 \mathrm{mg} / \mathrm{kg}, 295.11$ $\mathrm{mg} / \mathrm{kg}$ 로 전체 물고기의 평균 $85.38 \mathrm{mg} / \mathrm{kg}$ 보다 훨씬 높 은 값을 나타내었다. 육식성 어류(carnivores fish)는 강준 치와 쏘가리의 간에서 철의 농도가 평균값보다 높은 것 을 제외하고 특징적인 부위별 농도 분포를 나타내지 않았다.

\section{2. 부위별 중금속 평균 농도 및 농집 경향}

Table 3과 Fig. 3은 분석한 13 개 어종의 각 부위별 평 균 중금속 농도를 나타낸 것이다. 크롬, 망간, 니켈, 납은 아가미에 높은 농도값을 나타내었으며, 철과 구리, 카드 뮴은 간에, 아연과 비소는 위, 수은은 근육부에 높은 값 을 나타내었다. 기존의 보고서에 의하면 오염되지 않은 어류의 수은의 농도는 $0.2 \mathrm{mg} / \mathrm{kg}$ 이하이며(D'Itri, 1972), WHO Regiongal office for Europe의 보고에는 오염 지역 의 수은 함량이 $0.2 \sim 0.5 \mathrm{mg} / \mathrm{kg}$ 이다. 연구지역 물고기의 근육부 수은 농도가 $0.02 \sim 0.80 \mathrm{mg} / \mathrm{kg}$, 평균 $0.22 \mathrm{mg} / \mathrm{kg}$ 이며, 강준치와 배스는 각각 $0.47 \mathrm{mg} / \mathrm{kg}, 0.38 \mathrm{mg} / \mathrm{kg}$ 으로 오염 지역의 수은 함량을 나타내었다. 갈겨니, 꺽지, 끄 리, 메기, 붕어, 잉어, 참마자 등은 자연 수준 함량보다

Table 3. Average concentration for each part of whole fish

\begin{tabular}{ccccccccccc}
\hline Part of fish & $\begin{array}{c}\mathrm{Cr} \\
(\mathrm{mg} / \mathrm{kg})\end{array}$ & $\begin{array}{c}\mathrm{Mn} \\
(\mathrm{mg} / \mathrm{kg})\end{array}$ & $\begin{array}{c}\mathrm{Fe} \\
(\mathrm{mg} / \mathrm{kg})\end{array}$ & $\begin{array}{c}\mathrm{Ni} \\
(\mathrm{mg} / \mathrm{kg})\end{array}$ & $\begin{array}{c}\mathrm{Cu} \\
(\mathrm{mg} / \mathrm{kg})\end{array}$ & $\begin{array}{c}\mathrm{Zn} \\
(\mathrm{mg} / \mathrm{kg})\end{array}$ & $\begin{array}{c}\mathrm{As} \\
(\mathrm{mg} / \mathrm{kg})\end{array}$ & $\begin{array}{c}\mathrm{Cd} \\
(\mathrm{mg} / \mathrm{kg})\end{array}$ & $\begin{array}{c}\mathrm{Hg} \\
(\mathrm{mg} / \mathrm{kg})\end{array}$ & $\begin{array}{c}\mathrm{Pb} \\
(\mathrm{mg} / \mathrm{kg})\end{array}$ \\
\hline Muscle & 0.07 & 0.20 & 3.92 & 0.03 & 0.31 & 20.08 & 0.16 & 0.02 & 0.22 & 0.06 \\
Gill & 0.41 & 4.38 & 47.89 & 0.18 & 0.57 & 39.09 & 0.17 & 0.49 & 0.06 & 0.53 \\
Stomach & 0.16 & 2.43 & 63.30 & 0.10 & 3.76 & 85.38 & 0.35 & 1.79 & 0.13 & 0.34 \\
Liver & 0.05 & 2.81 & 238.66 & 0.08 & 7.75 & 41.47 & 0.39 & 2.27 & 0.20 & 0.38 \\
\hline
\end{tabular}



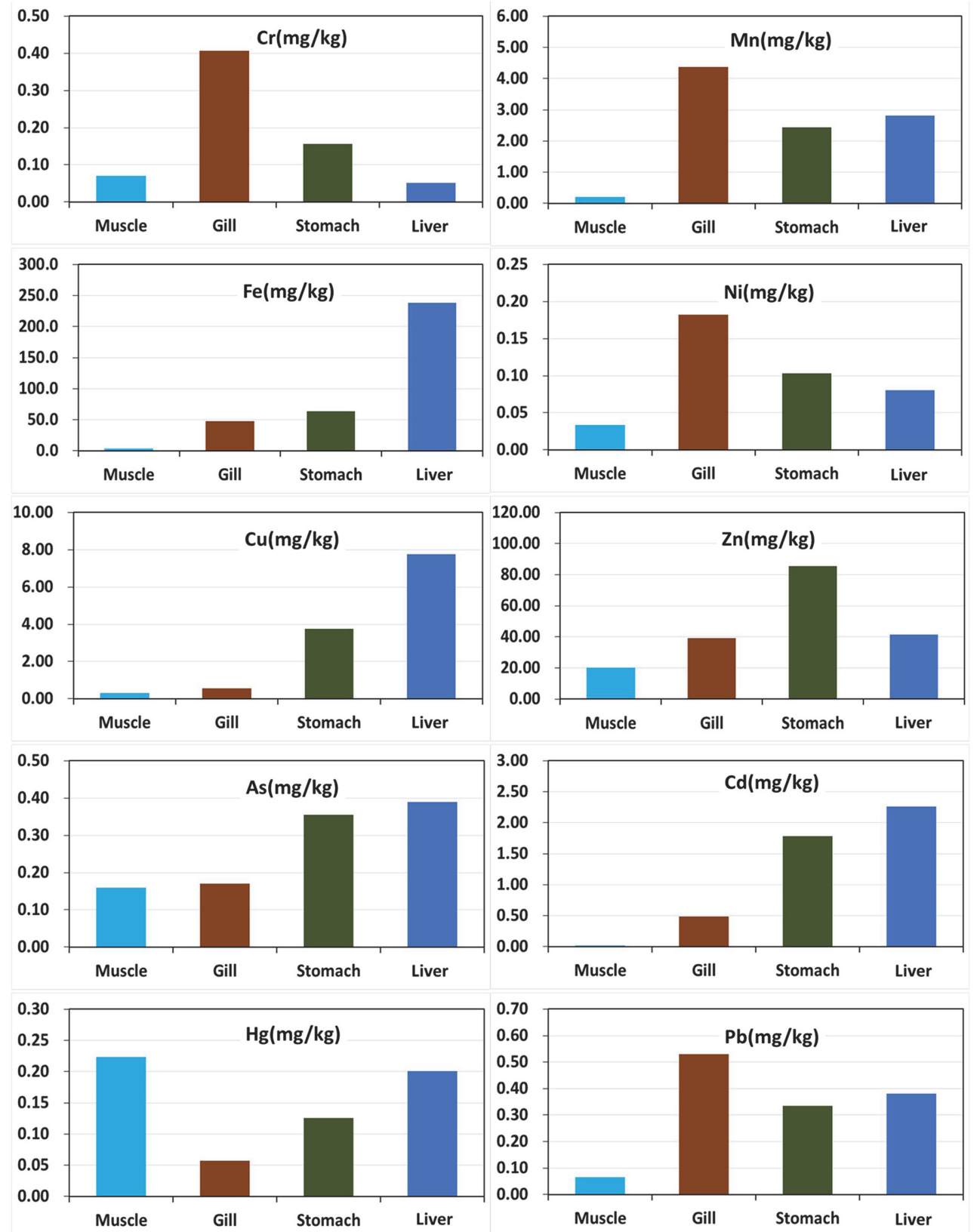

Fig. 3. Average heavy metal concentration by each part of whole fish.

낮으며, 우리나라 어류 기준치인 $0.5 \mathrm{mg} / \mathrm{kg}$ 을 초과한 물 고기는 없는 것으로 나타났다.

크롬은 위에 높은 값을 나타내는 떡붕어 1 개를 제외한 12 개 어종에서 아가미에 농집되며, 망간은 아가미 8개, 위 3 개, 간 2 개 어종, 철은 모든 어종에서 간에 농집되었 다. 니켈은 근육 2 개, 아가미 5 개, 위 5 개, 간 2개, 구리 는 위 1 개, 간 12 개 어종, 아연은 근육 1 개, 아가미 2개, 위 6 개, 간 4 개 어종에서 높은 값을 나타내었다. 비소는 근육 3 개, 아가미 1 개, 위 6 개, 간 6 개 어종, 카드뮴은 위 5 개, 간 8 개 어종에서 농집되었다. 수은은 근육 10 개, 위
1 개, 간 2 개 어종, 납은 아가미 7 개, 위 1 개, 간 5 개 어종 에 농집되었다. 따라서 물고기의 근육에는 수은이 농집 되며, 아가미에는 크롬, 망간, 니켈, 납, 위에는 니켈, 아 연, 비소, 간에는 철, 구리, 비소, 카드뮴, 납의 농도가 높 았다. 특히 크롬은 아가미, 철과 구리는 간, 수은은 근육 부에 높은 농집 현상이 뚜렷하게 나타났다.

각 원소별 농집 경향을 보면 크롬은 아가미-위-근육-간, 망간과 납은 아가미-간-위-근육, 철, 구리, 비소, 카드뮴은 간-위-아가미-근육, 니켈은 아가미-위-간-근육, 아연은 위 -간-아가미-근육, 수은은 근육-간-위-아가미 순으로 수은 
Table 4. Average concentration for each part of omnivores and carnivores fish

\begin{tabular}{|c|c|c|c|c|c|c|c|c|c|c|c|}
\hline Diet type & Part of fish & $\begin{array}{c}\mathrm{Cr} \\
(\mathrm{mg} / \mathrm{kg})\end{array}$ & $\begin{array}{c}\mathrm{Mn} \\
(\mathrm{mg} / \mathrm{kg})\end{array}$ & $\begin{array}{c}\mathrm{Fe} \\
(\mathrm{mg} / \mathrm{kg})\end{array}$ & $\begin{array}{c}\mathrm{Ni} \\
(\mathrm{mg} / \mathrm{kg})\end{array}$ & $\begin{array}{c}\mathrm{Cu} \\
(\mathrm{mg} / \mathrm{kg})\end{array}$ & $\begin{array}{c}\mathrm{Zn} \\
(\mathrm{mg} / \mathrm{kg})\end{array}$ & $\begin{array}{c}\mathrm{As} \\
(\mathrm{mg} / \mathrm{kg})\end{array}$ & $\begin{array}{c}\mathrm{Cd} \\
(\mathrm{mg} / \mathrm{kg})\end{array}$ & $\begin{array}{c}\mathrm{Hg} \\
(\mathrm{mg} / \mathrm{kg})\end{array}$ & $\begin{array}{c}\mathrm{Pb} \\
(\mathrm{mg} / \mathrm{kg})\end{array}$ \\
\hline \multirow{4}{*}{ Omnivores } & Muscle & 0.07 & 0.20 & 3.92 & 0.03 & 0.31 & 20.08 & 0.16 & 0.02 & 0.22 & 0.06 \\
\hline & Gill & 0.41 & 4.38 & 47.89 & 0.18 & 0.57 & 39.09 & 0.17 & 0.49 & 0.06 & 0.53 \\
\hline & Stomach & 0.16 & 2.43 & 63.30 & 0.10 & 3.76 & 85.38 & 0.35 & 1.79 & 0.13 & 0.34 \\
\hline & Liver & 0.05 & 2.81 & 238.66 & 0.08 & 7.75 & 41.47 & 0.39 & 2.27 & 0.20 & 0.38 \\
\hline \multirow{4}{*}{ Carnivores } & Muscle & 0.07 & 0.20 & 3.92 & 0.03 & 0.31 & 20.08 & 0.16 & 0.02 & 0.22 & 0.06 \\
\hline & Gill & 0.41 & 4.38 & 47.89 & 0.18 & 0.57 & 39.09 & 0.17 & 0.49 & 0.06 & 0.53 \\
\hline & Stomach & 0.16 & 2.43 & 63.30 & 0.10 & 3.76 & 85.38 & 0.35 & 1.79 & 0.13 & 0.34 \\
\hline & Liver & 0.05 & 2.81 & 238.66 & 0.08 & 7.75 & 41.47 & 0.39 & 2.27 & 0.20 & 0.38 \\
\hline
\end{tabular}

을 제외하고 대체로 아가미, 위, 간에 중금속이 농집되는 경향을 나타내었다. 기존의 연구에서 중금속 농도는 근 육에서 낮고 아가미 조직에서 높으며, 아연이 간에 농집 되는 경향은 본 연구 결과와 유사하다(Hwang, et al., 1989; Shin et al., 2010). 그러나 Hwang and Park(2006)의 해산 어류의 부위별 중금속 연구에서는 어종과 상관없이 간에 서 중금속의 농도가 높고, 아가미에서 낮은 값을 나타내 는 결과와는 차이를 나타내었다. 다른 연구에서는 수중 환경에 카드뮴이 존재할 경우, 어류 체내에서 축적되는 중금속의 양은 신장에 가장 많고, 다음은 아가미와 간, 췌장 순으로 농집되었다(Yayoi et al., 1986). 또한, Bawuro et al.(2018)의 연구에 의하면 물고기 체내 중금속 농도는 물고기의 종류, 먹이, 크기, 나이에 따라 다르며 부위별 로는 간에 아연, 구리, 납이 농집되고 카드뮴은 아가미에 더 높은 농도값을 나타내었다. 본연구에서는 간에 철, 구 리, 비소 카드뮴, 아가미에는 크롬, 망간, 니켈, 납이 농 집되는 경향을 나타내어 기존 연구와 약간의 차이를 나 타내었다. 물고기 체내 중금속은 항목에 따라 근육부, 아 가미, 위, 간 등에 일정한 분포를 보이지 않고 선택적으 로 축척된다는 것을 알 수 있으며, 많은 양의 중금속을 축적하는 능력이 있는 조직은 물고기의 오염 정도를 파 악하는데 선택적으로 이용할 수 있을 것으로 판단된다.

Table 4는 잡식성 어류와 육식성 어류의 각 부위별 평 균 농도를 나타낸 것이다. 중금속 농집 정도를 보면 근 육부에는 수은을 제외하고 다른 부위에 비해 대체로 낮 으며, 다른 항목은 잡식성 물고기가 높았다. 아가미 부위 가 다른 부위에 비해 높은 항목은 크롬, 망간, 니켈, 납 이며, 크롬을 제외하고 다른 항목은 잡식성이 더 높았다. 위 부위의 중금속 농도가 높은 항목은 망간, 구리, 아연, 비소, 카드뮴, 납이며, 잡식성이 육식성 물고기보다 훨씬 높은 값을 나타내었다. 간 부위에 중금속 농도가 높은 항 목은 망간, 철, 구리, 비소, 카드뮴, 수은 등이며, 수은을 제외한 나머지 항목은 모두 잡식성 어류가 더 높았다. 잡 식성 어류는 크롬과 니켈이 아가미, 수은이 근육부와 간
에 낮은 것을 제외하고 중금속 대부분이 모든 부위에 더 높았다(Fig. 4). 따라서 잡식성 어류는 위와 간에 육식성 어류는 주로 간에 농집되는 경향이 있으며, 육식성보다 잡식성 물고기가 체내에 중금속이 더 잘 농집되는 것으 로 판단된다.

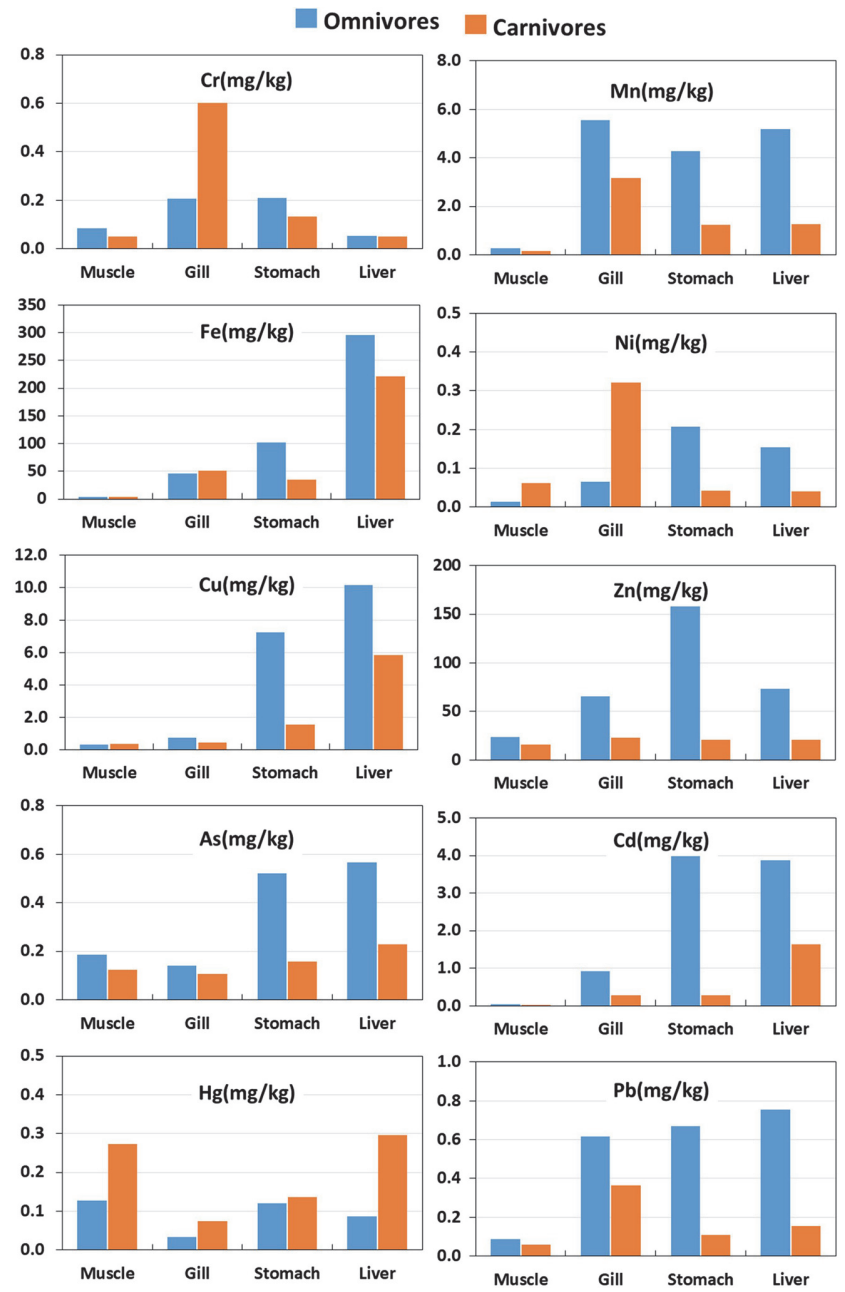

Fig. 4. Average heavy metal concentration by each part of omnivores and carnivores fish. 


\section{4. 결 론}

물고기의 부위별 중금속 농집 현상을 알아보기 위하여 안동댐, 임하댐, 영주댐 유역을 대상으로 13 어종 36 개체 에 대하여 부위별로 시료를 채취하여 분석을 수행하였다. 원소별 농집되는 부위는 어종에 따라 다르며, 먹이의 형 태에 따라 다르게 나타났다. 전체 평균 농도를 기준으로 근육부는 수은과 비소를 제외한 중금속 항목에서 다른 부위에 비해 낮게 나타났다. 부위별 농집되는 중금속의 종류는 아가미에 크롬, 망간, 니켈, 납이, 위에는 아연, 망 간, 니켈, 구리, 비소, 카드뮴, 수은, 납이, 그리고 간 부 위는 철, 구리, 비소, 카드뮴이 농집되는 경향이 뚜렷하 다. 잡식성 어류는 위와 간 부위에 중금속의 농도가 높 고, 육식성 어류는 주로 간에 농집되는 경향이 있으며, 육식성보다 잡식성 물고기의 체내에 중금속이 더 잘 농 집되었다. 물고기 부위별 중금속은 항목에 따라 선택적 으로 축적되며, 다량의 중금속이 축적되는 조직은 물고 기의 오염 정도를 파악하는데 선택적으로 이용할 수 있 을 것으로 판단된다.

\section{사 사}

이 논문은 환경부 대구지방환경청의 낙동강수계 환경 기초조사사업의 지원으로 연구되었으며 이에 감사드립니다.

\section{References}

Bawuro, A.A, Voegborlo, R.B. and Adimado, A.A. (2018) Bioaccumulation of Heavy Metals in Some Tissues of Fish in Lake Geriyo, Adamawa State, Nigeria. Jour. Environ. Public Health, v.2018, p.1-7. doi: 10.1155/2018/1854892
D’Itri, F.M. (1971) The Environmental Mecury problem; by F. M. D'Itri, CRC Press, CRC uniscience series, Cleveland, Ohio, 1972, 124p.

Hwang, I.D., Ki, N.S., Yang, G.S., Lee, J.H. and Kim, N.S. (1989) A study on the heavy metal contents in fish and sediments of the Mankyung river. Korean Jour. Environ. Helth Soc., v.15, p.33-49.

Hwang, Y.O. and Park, S.G. (2006) Contents of heavy metals in marine fishes, sold in Seoul. Analytical Sci. Tec., v.19, p.342-351.

Kim, J.S., Shin, M.J., Lee, J.E. and Seo, E.W. (2009) Heavy metal contents in tissues of Carassius auratus in Andong and Imha reservoir. Jour. Life Sci., v.19, p.1562-1567. doi: 10.5352/JLS. 2009.19.11.1562

Mason, A.Z. and Simkiss, K. (1983) Interactions between metals and their distribution in tissues of Littorina littorea collected from clean and polluted sites. Jour. Mar. Biol. Ass. U.K., v.63, p.661-672. doi: $10.1017 /$ S0025315400070971

Rajeshkumar, S. and Li, X. (2018) Bioaccumulation of heavy metals in fish species from the Meiliang Bay, Taihu Lake, China. Toxicology Reports, v.5, p.288-295. doi: 10.1016/j.toxrep.2018. 01.007

Seo, J.M., Kim, Y.H., Kwon, H.J. and Kim, J.J. (2019a) A Study on Heavy metal Characteristics of Sediments and inflow Suspended Solid of Andong and Imha-Dam. Jour. Miner. Soc. Korea, v.32, p.103-111. doi: 10.9727/jmsk.2019.32.2.103

Seo, J.M., Hong, S.M., Kim, Y.H. and Kim, J.J. (2019b), Studies on Heavy Metal Enrichment Property of Body in Japanese Crucian Carp from Andong and Imha Dam. Proceedings of the 74th Annual Meeting of the Geological Society of Korea and 2019 Fall Joint Conference of the Geological Sciences, 2019. 10. 2326, Jeju

Shin, M.J., Park, M.Y., Lee, J.E. and Seo, E.W. (2010) Heavy Metal Contents in Tissues of Fishes in Andong and Imha Reservoirs. Jour. Life Science, v.20, p.1378-1384. doi: 10.5352/JLS.2010. 20.9.1378

Yayoi, K., Koyama, J. and Ozaki. H. (1986) Heavy metal levels in tissues of fish exposed to cadmium. Bull. Japan Soc. Sci. Fish, v.52, p.2055-2059. 